\title{
An Analysis of the Path of Music Education Reform in Colleges and Universities from the Perspective of National Cultural Heritage
}

\author{
Li Li
}

Yangtze University School of Art, Jingzhou, Hubei, China

\begin{abstract}
Music education is one of the most important contents in the process of quality education in colleges and universities. With the deepening of the education system, how to make students have high musical literacy is particularly important. As a music teacher in colleges and universities in the new era, we should pay attention to the irreplaceable role of national culture in the reform of music teaching. From the perspective of national culture, this paper discusses the reform of music teaching, hoping to promote the development of music education in colleges and universities.
\end{abstract}

Key words: music education; national culture; the path of reform

Music teaching in colleges and universities should not only improve the effectiveness of teaching, but also pay attention to cultural heritage. On the basis of inheriting national music, music culture should be further developed. National music covers thousands of years of excellent traditional music in China, is an important national cultural content. As an important branch of Chinese traditional culture, national culture can fully display the life attitude, customs and spiritual outlook of all ethnic groups in China. In addition, the national culture contains high traditional cultural value, which is an important part of cultivating college students' musical literacy, that can not only make students pay attention to cultural development and inheritance, but also help them gradually establish correct values in their study. Therefore, in the process of music teaching, colleges and universities need to start from the characteristics of the development of the times, attach importance to the infiltration of national music culture, and do a good job in the inheritance and promotion of national music culture, so as to promote the progress and development of music teaching in colleges and universities.

\section{The Music Teaching in Colleges and Universities under the Perspective of National Cultural}

\section{Heritage}

At present, some colleges and universities in the teaching process can not fully realize the role of national culture in music teaching, but will focus on western music-related content. There are fifty-six ethnic groups in our country, each with different musical styles, and the analysis and study of national music is also the focus of the reform of music teaching in colleges and universities. Colleges and universities should innovate the original teaching mode from a systematic and comprehensive point of view and actively promote and inherit national music. At the same time, in the process of music teaching, teachers should pay more attention to cultivating students' innovation ability and creative ability.

As the saying goes, interest is the best teacher. Changing and innovating the teaching mode which originally focused

Copyright $(\underset{2}{ } 2021$ by author(s) and Frontier Scientific Research Publishing Inc.

This work is licensed under the Creative Commons Attribution International License (CC BY 4.0).

http://creativecommons.org/licenses/by/4.0/ 
on theoretical explanation, and constructing a new model of diversification and interest, are conducive to stimulating students' interest in learning and improving students' learning efficiency. In music teaching, teachers can use the Internet, pictures, animation and other forms of teaching content innovation, so that music knowledge can be more intuitive to present, and increase the fun and vivid teaching content. Music teaching has a strong artistic character. Through music courses, students can develop artistic cells, artistic feeling ability and music appreciation ability. Therefore, in the course of teaching, the content of mixing, harmony, and rhythm are the basic knowledge that students must master. Teachers need to introduce multimedia technology from these aspects, and then stimulate students' senses from the perspective of hearing, vision and so on. This can break the boring of the original classroom teaching to a certain extent, and bring students a variety of learning experience.

In addition, teachers also need to introduce multimedia equipment into music teaching to ensure that students can have a deep understanding of the music background. Through the understanding of music background knowledge, students can realize the unique charm of music, and then resonate with music, so as to provide assistance for having a solid foundation in music in the future.

\section{The Role of National Culture in Music Education in Colleges and Universities}

2.1 Support the development of music education

With the rapid development of society and economy, the spiritual culture and material culture of the Chinese nation are also making progress. National culture, like other cultures, needs to be inherited and protected. In the national culture, it contains the spiritual strength and cultural connotation of our country to realize the great rejuvenation of the Chinese dream, so it is of great significance to the protection and inheritance of the national culture. Through national cultural education, we can ensure that the national music culture is inherited and protected, and at the same time, we can build a solid foundation for building a modern music education system. As the main position of cultivating high-quality talents, colleges and universities must pay great attention to the teaching of national music culture.

\subsection{To make the modern teaching structure more perfect}

The basic purpose of music teaching is to enable students to master the knowledge and practical skills of music theory, so as to cultivate students' musical aesthetic ability and musical literacy, and then promote the development of social civilization. Paying attention to national culture plays an important role in constructing a perfect modern music teaching structure. National culture contains many excellent cultural elements, which can be used to promote the development of music teaching. Especially with the continuous development of quality education and curriculum reform, students develop in moral, intellectual, physical, aesthetic and labor fields in an all-round way, and enhance their comprehensive ability. Therefore, colleges and universities need to pay attention to music education and do a good job in the inheritance of national culture.

At present, compared with some mainstream disciplines, there is still a big gap in the degree of attention to music in some colleges and universities in China. In essence, colleges and universities should break the restrictions brought about by traditional teaching and better reflect the value and significance of music education, give full play to their own advantages, actively pay attention to the inherent differences between students, and from a diversified, multi-level perspective to train students with good musical aesthetic ability. In addition, music classroom teaching needs to be optimized according to the talent standards of the new era.

\section{The Effective Method of Music Education Reform in Colleges and Universities from the Perspective of National Culture}


3.1 Strengthen exchanges and interaction among the cultures of all ethnic groups

Dance, music and drama are the basic forms of national culture. In the process of promoting the reform of music teaching, colleges and universities should excavate the connotation of national culture and spirit, and use national music to embody historical culture, humanistic pursuit and life form. Then, based on the opportunity of the development of the new era, we should adopt reasonable methods to promote the reform of music teaching. In addition, teachers should explain to students the history of music development of different nationalities and their musical and artistic connotations. The collision of different music cultures can deepen students' understanding of music knowledge and form their own unique sense.

Therefore, colleges and universities should take the initiative to communicate with the music culture of different nationalities when carrying out the reform of music teaching, and promote the innovation of music teaching methods in the constant collision and exchange.

3.2 Introduce examples to explain the national music culture

In the process of music teaching, colleges and universities can use classroom expansion to introduce the traditional Chinese culture, so that students can learn more about the essence of national culture. For example, teachers can use various forms in the classroom to explain and display the Hmong, Tujia and other ethnic music, so that students can feel different nationalities, different regions of the music culture which has unique connotations. In addition, teachers also need to carry out in-depth analysis of the musical aesthetic characteristics of national music culture, so that students realize the aesthetic connotation, so as to form a good aesthetic ability and improve students' artistic literacy.

3.3 Creative teaching to the national music culture

As a multi-ethnic country, our country has a long history and rich content of national culture. In the course of music teaching, colleges and universities should integrate the unique national music culture into classroom teaching, so as to make the music teaching system of colleges and universities more perfect and the content more substantial. In addition, there are obvious differences in music between different nationalities in different eras, so schools, teachers and students need to be innovative, research and analysis of different music culture. We are not only to feel its artistic charm, but also to take the initiative to inherit its essence, and enable it to innovate and develop.

3.4 Better reflect the national culture in the process of music teaching

In the process of music teaching, teachers should not only cultivate students' artistic aesthetic ability, but also enhance students' national pride. In addition, teachers also need to take the initiative to cultivate students' gratitude. China is a famous state of etiquette, many national cultures also have the expression of gratitude elements. Therefore, teachers should guide students with gratitude to learn music knowledge. Teachers can use the diversified way to actively tap the aesthetic connotation of music culture, show the characteristics of national culture, and guide students to carry out analysis and discussion, improve students' aesthetic ability and national self-confidence.

\section{Conclusions}

To sum up, music, as a highly artistic subject, can effectively cultivate students' artistic aesthetic ability and comprehensive quality. With the gradual progress of curriculum reform, colleges and universities need to cultivate students' comprehensive musical literacy. In the process of music teaching, it is necessary to cultivate students' perceptual and aesthetic ability, and also strengthen the development and inheritance of national culture. In the teaching process, teachers should pay attention to carry forward and inherit the traditional culture of the Chinese nation, which can not be adopted in a rigid way, but to take its essence, and on this basis, content innovation, and ultimately into the music teaching. As a music teacher in the new era, we also need to improve the teaching methods of music, and always carry out 
innovative principles throughout the teaching process to help students lay a solid foundation of music.

\section{Conflicts of Interest}

The author declares no conflicts of interest regarding the publication of this paper.

\section{References}

[1] Zhou L.J. (2021). Discussion on the Teaching Concept and Teaching Mode of Music Education in Colleges and Universities. House of Drama, (24):58-59.

[2] Zhang X. (2021). The Heritage of National Music Culture in Music Education in Colleges and Universities. House of Drama, (24):95-96.

[3] Wang Y.Z., Zhang W. (2021). Discussion on the Reform of Music Education in Colleges and Universities from the Perspective of Traditional Cultural Heritage. House of Drama, (24):97-98.

[4] Jiang L. (2021). Music Education Teaching and Practice in Colleges and Universities--Review of Music Education in General Colleges and Universities. China Journal of Education,(08):128.

[5] Wang X.N. (2021). The Path Analysis of Perfecting Music Classroom Teaching in Colleges and Universities under the New Situation. House of Drama, (23):1.

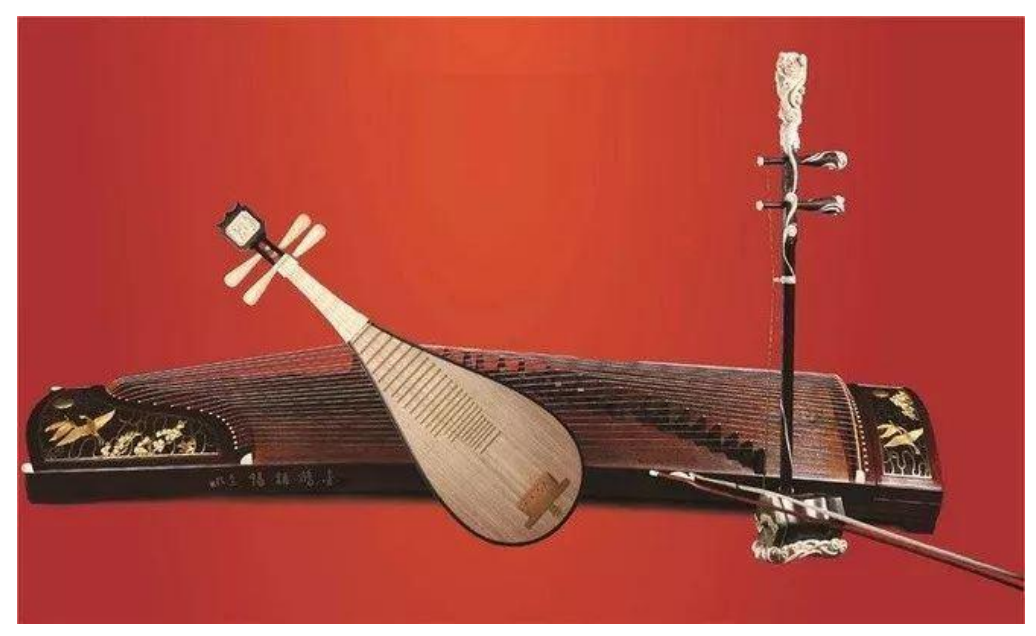

